\title{
Exploring the Coping Strategies of University Library and Information Organizations in the Construction of National Think Tanks
}

\author{
Wu Hong \\ Jianghan University of Wuhan Jianghan University Library, Wuhan Hubei, China, 430056
}

Keywords: colleges and universities, library and information institutions, national think tanks, construction, coping strategies

\begin{abstract}
The construction of think tanks will reflect the level of national soft power. Therefore, in order to promote China's stable development and improve national strength and competitiveness, it is necessary to strengthen the construction of think tanks. The study found that library and information agencies have a wealth of information resources and information analysis talents, which play an important role in the research and construction of think tanks. This paper expounds the overview and development process of think tanks. By analyzing the problems existing in the construction of think tanks in China, this paper puts forward the countermeasures of college library information structure in the construction of national think tanks.
\end{abstract}

\section{Introduction}

In 1971, American political scientist Paul Dixon compiled "Think Tank", which mainly introduces think tanks. American scholar Howard Wiyalda believes that think tanks are the main institutions that study public policy issues. They are different from companies and groups. Their main purpose is not to make profits, but to influence government decision-making. In short, think tanks are non-profit, public-strategic institutions whose primary goal is to influence government policies. They are also known as the "outside brains" of government decision-making. The study found that Western countries think tanks can influence government decision-making by conducting research on predictive effects and transferring talents to government departments. At the same time, they will promote their ideas through conferences and public events. At this stage, most of China's think tank construction forces are intelligence research organizations such as the government and the Academy of Social Sciences. Most of its research content involves the feasibility of research and construction of think tanks, and provides suggestions and references for government and enterprise decision-making. Library and information institutions have the responsibility of developing literature information resources, and they have important links with the construction of think tanks. Therefore, in order to promote the development of think tanks and strengthen the construction of national think tanks, it is necessary to deeply study the countermeasures of college library and information institutions in the construction of national think tanks. 


\section{Think Tank Overview and Development Process}

\subsection{Think Tank Overview}

As early as World War II, the term think tank was put forward, referring to the secret room of scientists and soldiers involved in military strategy development. At present, most people think that think tanks are relatively independent policy research institutions. Relevant personnel can use research methods to analyze and study public relations policy issues, and make corresponding suggestions for governments and enterprises. The main research object of the think tank is government policy, which mainly provides services to the country. Think tanks are relatively independent, non-profit organizations that study policy policies and policies through relevant knowledge, which in turn affects national policies. Think tanks represent the country's soft power, which has an important impact on the speed and stability of the country's development.

\subsection{Think Tank Development Process}

In the 19th century, with the development of human society, the world political situation and economic order changed, the social division of labor was gradually refined, and the scientific decision-making of the government was increasing. Therefore, in order to ensure the scientific, democratic and rational decision-making of the government, it is necessary to build a think tank to provide professional consulting services for government departments. With the steady development of think tanks, its influence on national development is deepening. There are many types of think tanks in Western countries, such as the RAND Corporation of the United States and the London Institute for International Strategic Studies in the United Kingdom, they have important influences on the political, economic, and cultural aspects of the country.

The study found that we can divide our think tanks into national think tanks, college think tanks and folk think tanks. When Chinese experts and scholars participated in the government work, they began construction on behalf of the official think tank of China, and the time was in the 1970s. With the construction and development of the official think tank, some experts and scholars have established an organization to study the political economy, which indicates that the Chinese people's think tanks have gradually developed. Until the 1990s, with the development of colleges and universities, China began to build college think tanks, study China's government policies, and provide relevant recommendations for the country. At this stage, China has not built the world's top think tanks.

\subsubsection{Official Think Tank}

Government-funded research organizations that study government policies and provide consulting services to the government are official think tanks. The official think tank is dominated by government departments, and most of the researchers in the think tank belong to civil servants. At this stage, most of China's think tanks are official think tanks, and in fact, important organizations that influence government decision-making. In addition, the official think tank can influence the decision-making and reform of our government through its research results. Most of the research projects of the official think tank are entrusted by government departments. The research results and recommendations of the think tanks will be reported step by step through internal reporting, which will appear in the programmatic documents of the party and the government. Since the official think tank is funded by the government, its research results will be quickly passed to the government, and government feedback can be quickly obtained.

\subsubsection{University Think Tank}

The institution that is organized by the university and provides policy advisory services to the 
government and the masses is the think tank of the university. Under normal circumstances, college think tanks are funded by universities or alumni entrepreneurs, and are studied by experts in various disciplines in the university or senior managers in industries and enterprises. Compared with other think tanks, college think tanks provide more policy advice services for the government and the masses, and they have a large number of experts and scholars in different disciplines, so their research capabilities are strong.

\subsubsection{Folk Think Tank}

The public policy research organization funded by the private sector is a private think tank. Its source of funds does not include government departments, so its independence is strong. Compared with the official think tanks and college think tanks, the private think tanks pay more attention to the effectiveness and pertinence of research, which can timely identify market demand and market development direction; folk think tanks pay more attention to social fairness and fairness. In addition, compared to the official think tanks and college think tanks, the folk think tanks have a wide range of topics.

\subsection{The Role and Significance of Think Tank Construction}

The quality of think tank construction has an important impact on social development and government management. First of all, China is in an important stage of reform. Before promulgating and implementing important decisions, it is necessary to analyze in depth the level of China's political and economic development and ensure that decision-making can promote the stable development of China. Due to the large number of government departments, it is necessary for the think tank to analyze the level of China's political and economic development. In addition, although China has a large number of think tanks, the official think tank is still the main institution that influences China's political and economic decision-making. Therefore, in order to promote the gradual deepening of China's political and economic reforms and achieve the goal of building a legalized society, it is necessary to strengthen the construction of national think tanks. Library and information agencies need to give full play to their advantages in literature resources, research talents, etc., to help China's think tank construction.

\section{Problems in the Construction of Think Tanks in China}

In recent years, the requirements of think tanks at all levels of government in China have been continuously improved, and think tanks have also made considerable progress. As of 2016, there are 6,846 think tanks in the world, and 1,835 in the United States, the number of think tanks is the highest in the world; there are 435 think tanks in China, and the number of think tanks is the second in the world. With the rapid development of China's think tanks, we can find some shortcomings in the construction of think tanks in China. Although there are many think tanks in China, their quality is not high enough. At present, China does not have a think tank selected into the world's top ten think tanks. The study found that there are several shortcomings in the construction of think tanks in China:

\subsection{Think Tank Research Ability is Weak}

Different from Western countries, most of China's think tank projects are entrusted by the government. Due to the scope of the project, think tank research lacks predictability. In addition, China's think tanks have weak research and judgment capabilities, and their policy research capabilities and research levels are not high enough to meet the government's requirements for think 
tanks.

\subsection{Think tank decision-making Influence is Weak}

Think tanks can influence public policy by studying government-sponsored projects or providing training advisory services to government workers. Although there are many research projects in China's official think tanks, their research is lagging behind, and it cannot effectively solve some practical problems. In addition, most of the think tank projects commissioned by the government are under the responsibility of the official think tank, which makes the influence of China's private think tanks and university think tanks weak.

\subsection{Think Tank Public Opinion is Weak}

Think tanks can influence public opinion through their own research topics, and the main purpose of think tank setting issues is to provide advice for government-related policies. However, the suggestions put forward by some think tanks are lack of pertinence and effectiveness, which makes their social opinion influence weak.

\subsection{Think Tank Results Conversion Rate is Low}

China's think tank brand awareness is weak, and the results of think tanks have not been vigorously promoted. In order to influence public decision-making through research results, think tanks need to ensure that their research results are recognized by the masses. Therefore, it is necessary to raise the awareness of think tanks so that the masses can fully understand the work content and role of think tanks and their impact on the masses, society, and the state. Effectively promote the stability and sustainable development of think tanks. At this stage, the promotion and promotion of China's think tanks is weak, and the results of their research cannot be fully utilized. The research results of most think tanks in China have not been released to the masses, and the researchers have not published relevant opinions through various media. Only extensive publicity or targeted publicity cannot improve the visibility of think tanks. Usually think tanks use papers or research reports to present their findings. Most of China's think tank research projects are entrusted by the government. Therefore, the results of the research will be reported by internal reporting methods, and they will not be fully presented to the masses. As a result, the results of the think tank research have not been implemented.

\section{The Coping Strategies of University Library and Information Structure in the Construction of National Think Tanks}

\subsection{Collecting Literature}

The study found that the quality of information resource collection will affect the research results of think tanks and the quality of think tank construction. At the same time, the construction of think tanks will be affected by changes in social economic and political policies. Therefore, when building think tanks, it is necessary to make appropriate adjustments based on changes in social economic and political policies and to make recommendations for the system of state and enterprise policies to ensure the state and enterprises. The rationality and effectiveness of public relations affairs and policies. Therefore, the library and information institutions in colleges and universities should not only include professional books, periodicals and other materials in various disciplines, but also include "grey literature materials" and "thinking pool products" into the collection 
resources. University libraries can obtain such valuable materials by accepting donations, obtaining authorized copying materials, etc., and the library needs to process them to form valuable knowledge to provide a basis for the research and construction of think tank projects.

\subsection{Gathering Talents}

Different from some social libraries, colleges and universities light and information agencies can communicate with experts and scholars in various sciences in a timely manner, and can invite them to serve as consultants. Experts and scholars of various sciences can participate in the research and construction of national think tank projects. In recent years, with the rapid development of colleges and universities, colleges and universities have selected high-educated talents such as masters and doctors when hiring talents. In addition, university library and information agencies need to fully understand the characteristics and advantages of internal and external talents, and establish a stable and high-level think tank service team to provide talent support for think tank construction. Different from other disciplines, library and information science can deeply analyze, mine intelligence information, formulate information retrieval strategies, etc., and promote the stable development of think tanks. University library staff have accumulated a large amount of intelligence analysis and practical experience in long-term work, and have mastered intelligence analysis skills, which plays an important role in research and construction of think tank projects.

\subsection{Using Scientometrics to Evaluate Think Tank Results}

In recent years, think tanks have developed rapidly around the world, and they are of great significance to ensuring the scientific and effective policies of the state and enterprises. But what is the influence of think tanks? How to judge the role of think tanks in social, economic, and government decision-making? Some experts and scholars at home and abroad evaluate the performance of think tanks through experts or peer evaluation. For example, Japan invites relevant experts and scholars to evaluate a certain indicator of the think tank. Whether the performance evaluation of think tanks can be carried out in a scientific way, whether a perfect and scientific rating mechanism can be established is an important factor affecting the development of think tanks. Canadian scholar Donald Eberson has used the index evaluation method to evaluate the influence of think tanks. It points out that the scientific evaluation of think tank influence can be quantitatively evaluated by analyzing the main media clicks, the probability of citing the results of the think tank research, and the number of attendance at the congressional hearings. And Donald Eberson used this method to analyze the influence of some think tanks in Canada and the United States. The study found that such assessment methods and library intelligence agencies use journals, papers, impact factors and other quantitative indicators to analyze their influence. After long-term development, library and information science has formed a scientific measurement method and content, and its measurement indicators play an important role in ensuring the accuracy and effectiveness of library evaluation. Therefore, efficient library and information institutions can participate in the evaluation of think tank influence to ensure the scientificity and effectiveness of metrological indicators and quantitative evaluation mechanisms.

\subsection{Building a Think Tank Information Platform}

In the construction of the think tank information platform, it is necessary to build the information needs based on the think tank, and provide corresponding intelligence services according to the characteristics of the think tank. When building a think tank information platform, it is not only necessary to collect, organize and preserve a large amount of literature resources, but also make full 
use of technologies such as network technology and information technology to deeply explore the development rules of available information resources and reasonably explore, process and analyze these information resources. Provide a basis for research and construction of think tanks. The library and information organization can construct a one-stop search function, process and analyze the retrieved information resources, and form corresponding information according to the requirements of the think tank to provide information resources for the research and development of the think tank. Since the think tank information platform contains research from multiple research institutions, it can provide support for the development of think tanks, which plays an important role in promoting the development of think tanks.

\subsection{Using Key Technologies to Preserve Think Tank Results}

With the steady development of human society, think tank theory, technology, and policies are constantly improving. The think tanks of all countries in the world will produce a large number of products every year, including research reports, academic works, academic papers, etc. (such as: RAND Corporation "Rand Review"). Think tanks can use their products to promote their own research results, thereby affecting government and corporate policies and decisions. At this stage, the research results of think tanks have become an important basis for governments, think tanks, and enterprises in the world to formulate policies and decisions. With the rapid development of think tanks, various university library and information agencies are actively collecting, collating and using the results of think tank research. University information and information institutions have literature analysis technology, digital permanent preservation technology, associated data technology, information classification and indexing technology, etc. University library and information institutions can make full use of various technologies they own to collect various "grey" documents. By collecting, organizing, and using these "grey materials", you can provide valuable information for think tank scholars while enriching library collection materials.

\section{Conclusion}

In summary, the construction of think tanks is of great significance to building a rule of law society and improving the effectiveness and scientificity of government policies and decisions. In order to promote the development of think tanks towards personalized services and improve the value of think tanks, it is necessary to make full use of the advantages of university library and information institutions in terms of information resources and talents. In addition, colleges and universities also need to continuously improve their soft power and lay a solid foundation for the development of think tanks.

\section{References}

[1] Fang Yuan. Research on Service Innovation of Party School Library under the Vision of Modern Think Tank Construction [J]. Office Business, 2016(3):186-186.

[2] Xiangjin Kong, Changkai Sun, Deliang Wen. Status Quo and Development Strategy of the Research Institute of University Think Tank Nature [J]. Modern Education Management, 2016(5): 64-68.

[3] Nan An, Zhongming Zhu. Think Tank Information Organization Strategy and Its Challenge in Big Data Environment [J]. Think Tank Theory and Practice, 2017, 2(3): 25-35.

[4] Fengxia Xian. Functional Positioning of University Libraries in Fujian Province with Service Think Tank Construction [J]. Library Journal, 2017(5): 13-17.

[5] Ruili Geng. The Role of Information Science in the Construction of Think Tanks in Big Data Environment [J]. Library and Information Research, 2016(2):19-25.

[6] Xinxin Qiao. Library Transformation and Construction Strategy Based on Think Tank Concept [J]. Journal of Agricultural Library and Information Sciences, 2016, 28(9): 13-16. 